\title{
Activating the Monuments \\ The Ritual Use of Cairns in Bronze Age Norrland
}

\author{
Hans Bolin
}

\begin{abstract}
This article deals with cairns and stone-settings in Northern Sweden. The central questions are: what was the meaning of the cairns, who built them, and what were the intentions of the people in doing so? Cairns and stonesettings do not only represent a kind of permanent and completed graveconstruction for individual burials. The ritual use of cairns and cairn-like stone-settings also involved a broad spectrum of ritual activities. It is here suggested that the cairns should be related to kinship groups and considered as long-term monuments, which were continually rebuilt and activated in the local ritual.
\end{abstract}

Hans Bolin, Department of Archaeology, Stockholm University, SE-106 91 Stockholm, Sweden.

This article is about the cairns and stonesettings in the coastal area of Northern Sweden (Norrland). The tradition of building cairns and stone-settings in the coastal area is generally ascribed to the Bronze Age and Iron Age. The central questions discussed here are: what was the meaning of the cairns, who built them, and what were the intentions of the people in doing so? I will argue, by using a few examples from Norrland, that cairns and cairn-like stone-settings should not necessarily be interpreted as permanent and "completed" graveconstructions for individuals. The ritual use of cairns was a continuous religious practice which involved a broad spectrum of activities. The deposition of bones and the frequent rebuilding of the cairns were repeatedly done to activate the cairn-monuments in a attempt to communicate with the higher powers.

\section{DEPARTURE}

Cairns and cairn-like monuments occur widely in different parts of Sweden, Norway and Finland. Figure 1 shows the distribution of cairns in the coastal and inland areas of Sweden. Variations in type and construction exist within the different cairn-areas (Selinge 1974).

Fig. 1. The hatched areas show the distribution of cairns along coastal areas in Sweden. There is also a frequent occurrence of cairns in the inland parts of southem Sweden. The map is based on data from

Selinge

1974: $52-53$ and Hyenstrand 1979:137.

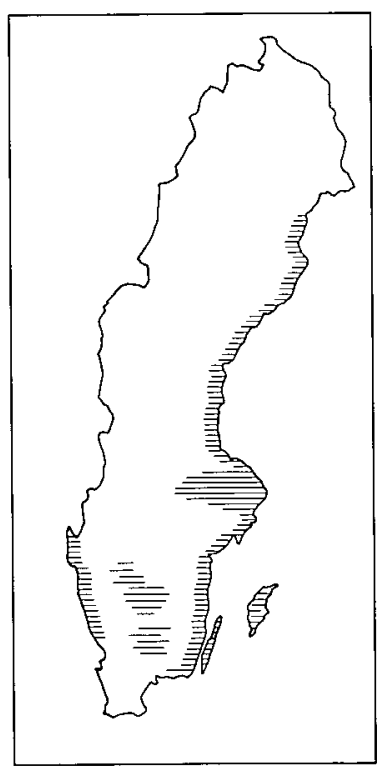

The discussion about the ritual use of cairns is vast. It is generally held that the use of Bronze Age cairns and cairn-like stonesettings is similar to the ritual use of Bronze Age mounds, that is, they represent burial- 
monuments raised over individual persons (e.g. Baudou 1968; Kristiansen 1987:79; Larsson 1994; Stjernquist 1993:125). Although the secondary use of Bronze Age mounds in southern Sweden has been studied and discussed in some detail (e.g. Jennbert 1993; Olausson 1993), the same attention has not been directed towards the cairns. A more general discussion of the "afterlife" of monuments and their ritual significance during different periods has been presented by Richard Bradley (1993), among others.

There is no intention in this article to make a detailed comparison between the archaeological evidence in Norrland and mounds or cairns in other areas. Even if it might seem both possible and relevant to draw parallels, it is not an issue dealt with in this article. This does not mean that the cairns along the Norrlandic coast should be considered as unique or special compared with the cairn-material in other areas. The purpose of this study is, after all, to illuminate the prehistoric conditions in Norrland and not the inter-regional relations or influences. My main intention is to show that a lot of cairns and cairn-like stone-settings were continually rebuilt and ritually used during a very long time.

There are roughly over 2,300 cairns and stone-settings distributed along the northern coast but they are not represented at all in the interior of Norrland. The coastal cairns in Norrland have generally been compared to a similar burialtradition in south Scandinavia. It has, for example, been suggested that the northern cairns were built by south Scandinavian farmers, seafarers and traders who died and were buried during their journeys to Norrland (e.g. Larsson 1994:129; Baudou 1992:100). I don't find this kind of diffusionist approach very convincing. The tradition of building cairns, mounds and stone-settings is obviously an external influence, internalized in different contexts, but a "new" type of artefact or a "new" tradition does not automatically mean that there is a migration of "innovators". We have to accept that those who lived along the coast were also involved in the process of introducing and reproducing the tradition of building cairns. Further, there is no convincing theory or any illuminating evidence within the cairn-material that supports the suggestion that the cairns were necessarily built as permanent and "completed" graves for special selected individuals or families (e.g. Baudou 1968; Salo 1983; Selinge 1979). Undoubtedly, some cairns do have remains of stonecists suited for inhumation burials, but those cairns, in my opinion, just represent a very early burial practice (see Baudou 1968:102), perhaps a late Neolithic/ Early Bronze Age reminiscence which subsequently disappeared when the cairns were later re-used. Despite these early burial constructions it is necessary to be careful when using terms like "primary grave", "secondary grave", "founder's grave", etc. (e.g. Kaliff 1997:68-78). This should not be seen as just a semantic quibble of words, but rather as a serious attempt to explain the meaning of the cairns and the way they were used. I will return to this discussion further on in this paper.

Excavations of cairns and stone-settings in the province of Ångermanland in Norrland have usually resulted in very few finds and artefacts. Only a few cairns have contained artefacts or depositions of bones (Baudou 1968:30-31). The bonematerial that has been found in excavated cairns and stone-settings derives from both animals and humans, and is often very fragmented and small. As we can see from the table in figure 2, the amount of boneremains in the cairns is scanty, usually less then $0.1-0.2$ litres. It is reasonable to assume that only a very small part of the cremated and uncremated bones was deposited in the cairns.

In Evert Baudou's survey only 14 cairns and cairn-like stone-settings contained animal and human bones. That is only $30 \%$ of the total number of excavated cairns (Baudou 1968). Another interesting detail in the figure is that almost every cairn-structure is described as disturbed in one way or another. Note, for example, that the inner construction, a $1.5 \mathrm{~m}$ long stonecist, in cairn 29:10 in Nätra parish is built on top of a charcoal and bone 


\begin{tabular}{|c|c|c|c|c|}
\hline Parish & Number & Finds & m a $\mathbf{l}$ & Comments \\
\hline Grundsunda & Raä 133:2 & cremated human bones, $0.15 \mathrm{I}$ & 35 & fallen stone slabs, charcoal \\
\hline Arnäs & Raä 9 & bone from goat & 55 & charcoal \\
\hline Själevad & Raä 8:1 & $\begin{array}{l}\text { cremated human bones, } \\
\text { female, glass bead }\end{array}$ & 55 & disturbed structure, charcoal \\
\hline Själevad & Raä 10:2 & $\begin{array}{l}22 \text { cremated human bones, } \\
\text { female }\end{array}$ & 35 & disturbed structure, charcoal \\
\hline Själevad & Raä 25:1 & bones from pig & 40 & fallen roof-slab in the cist \\
\hline Nätra & Raä 29:1 & bones from reindeer & 47 & disturbed structure \\
\hline Nätra & Raä 29:2 & cremated bones in both cists & 45 & $\begin{array}{l}\text { disturbed structure, charcoal, } \\
\text { both cists are } 1.5 \mathrm{~m} \text { long }\end{array}$ \\
\hline Nätra & Raӓ 29:4 & 1 fragment of cremated bone & 40 & disturbed structure, coal \\
\hline Nätra & Raä 29:10 & cremated bones in the cist & 37 & $\begin{array}{l}\text { a } 1.5 \mathrm{~m} \text { long cist built on top } \\
\text { of a bone and charcoal layer }\end{array}$ \\
\hline Nätra & Raä 31 & bones from reindeer in the cist & 45 & disturbed structure, pits \\
\hline Vibyggerå & Raä 27:5 & $\begin{array}{l}\text { cremated human bones, } 0.251 \text {, } \\
\text { male }\end{array}$ & 35 & disturbed structure \\
\hline Vibyggerå & Raä 27:9 & $\begin{array}{l}\text { cremated human bones, } 0.3 \mathrm{l} \text {, } \\
\text { female }\end{array}$ & 34 & $\begin{array}{l}\text { disturbed structure without } \\
\text { cist and stone-packing }\end{array}$ \\
\hline Vibyggerå & Raä 28:3 & $\begin{array}{l}8 \text { fragments of cremated } \\
\text { human bones }\end{array}$ & 38 & disturbed structure, pits \\
\hline Vibyggerå & Raä 28:5 & cremated human bones, $0.05 \mathrm{I}$ & 40 & no distinct form, uncertain \\
\hline
\end{tabular}

Fig. 2. Table of excavated cairns and stone-settings with boneremains in the district of Angermanland. Source: Baudou 1968.

layer, apparently in a later stage. In view of these conditions it is, in my opinion, necessary to question the interpretation of the cairns as a permanent and "completed" grave-construction. As John Barrett has maintained, we must recognize that funerary and ancestral rites were probably only part of a broad spectrum of activities which contributed to the programme of monument-building (Barrett 1994:54). The cairns in Norrland should therefore rather be considered as ritual monuments that were partly meant to be activated with small amounts of bones from animals and humans.

\section{CAIRNS, STONE-SETTINGS AND REBUILDINGS}

Cairns and stone-settings are ancient constructions built up with stones. It is mainly held that the difference between the two is a question of size where the cairns are considered to be higher and bigger, but of course there are quite a few that fall "in between" the two categories. From now on the term "cairn" will also include the cairn-like stone-settings. When it comes to external shape and details of construction, there is a wide range of classificatory elements in the cairn-terminology. Historically the typology of ancient monuments has been partly realistically and partly artistically illustrated (see fig. 3).

The classification system in current use has several structural similarities with the typology in the table from the $19^{\text {th }}$ century. The main reason for classifying the cairns is to achieve quantifiable and comparative data, which is supposed to make it easier to handle the material (Selinge 1986:7-50). This method of putting cairns, mounds and stone-settings into uniform categories has, however, also tended to simplify and stereotype the constructions into "ideal types", usually with very little congruence with real conditions. In my opinion, the cairns and the stone-settings in general do not have such a distinct external shape that fits into this kind of elaborate classification system (the variation in external shape is so extensive that such a system would be too complex and probably very difficult to 


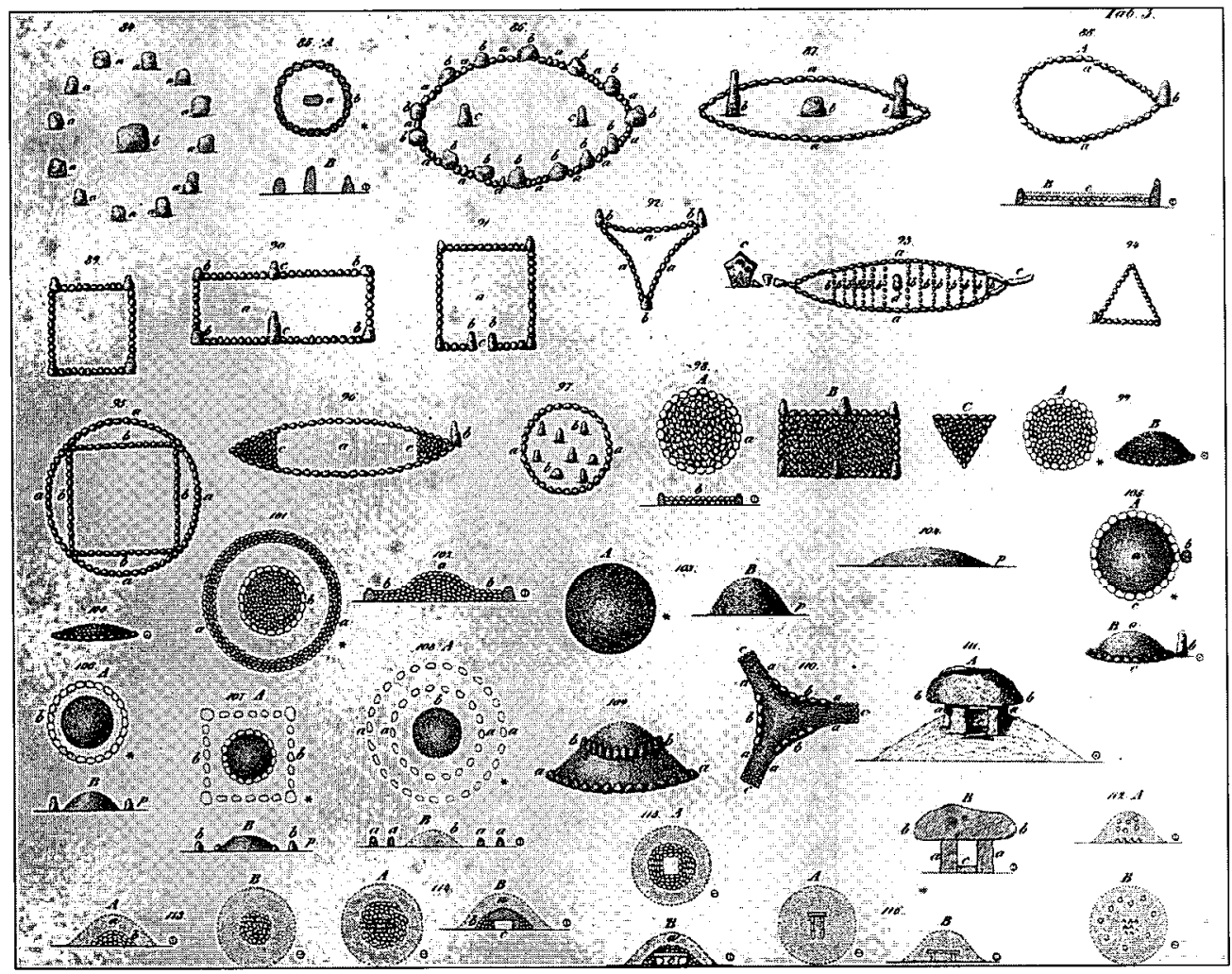

Fig. 3. The table shows one of J.H. Wallman's fanciful illustrations of ancient monuments from 1838. The classification system in current use has several structural similarities with the typology in Wallman's table. After Wallman 1838, Tab. 3.

work with). Almost every cairn in the survey reports are described as "disturbed" in one way or another (The Department of Ancient Monument Survey, the Central Board of National Antiquities). A close look at the structure of the cairns and stone-settings along the coast in northern Sweden makes this classification quite insignificant. One illustrative example of this is a stone-setting from Yttertavle, Umeå parish, in Västerbotten (see fig. 4), which before excavation was classified and described as rectangular in shape. As we can see, the rectangular classification is not discernible and can rightly be questioned. The stone-setting in figure 4 is not unique in this respect. Many of the cairns and stone-settings seem to have a rather indeterminable shape, and so far there has not been any satisfactory explanation for this. Usually these cairns are considered as plundered by later treasurehunters (Baudou 1968:51). This may be true for some of the cairns but definitely not for all of them.

Shape, form and spatial distribution are, besides chronology, the most fundamental axes of variation in material culture that archaeologists use. They are essential to describing, classifying and analyzing the material record (Carr \& Neitzel 1995:3). I agree that this is fundamental, but the formal classification mentioned above is not satisfactory when explaining and describing the cairnphenomena. The formal qualities of the cairns should not be considered as permanent and static (and hence determinable to any fixed point in time). The cairns and stone-settings in Norrland were instead continuously used and were frequently rebuilt. Evert Baudou, who 
has excavated and studied the coastal cairns in Norrland, has in several cases shown that there existed different phases when the cairns were reconstructed (see fig. 5).

The rebuilding of the cairn to the left in figure 5 is interpreted by Baudou to have occurred in the western part when a new inner stone-cist was built and the cairn was extended to the west. The cairn to the right in the figure is interpreted to originally have contained a 2 $\mathrm{m}$ long inner stone-cist, which at some point was divided into two smaller cists when the cairn was again rebuilt. Only a few burnt bones were found at the bottom of one of the cists (ibid. 1968:40). Usually one cannot expect to find evidence for more than one phase of rebuilding (the latest one) in the cairns, because the structural remains of any former rebuilding are probably no longer visible. It is interesting, however, to note that finds of cremated bones occur in several cairns containing larger cists of a man's length (e.g. 29:2 and 29:10 in Nätra parish). These conditions further support the interpretation of the cairns as re-used and rebuilt monuments.

Some of the cairns in Västerbotten and in the Mälar Valley in central Sweden show a similar tendency with different phases of rebuilding (Thålin 1966; Hyenstrand 1966). Baudou's example here serves to show my point of departure for further interpretation of the cairns in Bronze Age Norrland. Another example of rebuilding phases is shown in figure 6 .

The cairn-structure Vibyggerå27:7-9 seems to have been built in several stages and is described as a complex of three structures, closely erected next to one another (Baudou 1968:177-8). In my opinion, this is a very illuminating example of indeterminable construction-shapes. Once again, I will emphasize that the external cairn-shapes, as they occur in reports and specifications, do not seem to fit in any formal typology. It is reasonable to claim that the external shape and architecture were very important in the ritual setting. Anyway, whatever shape they had when they were first constructed and later rebuilt, it seems that they

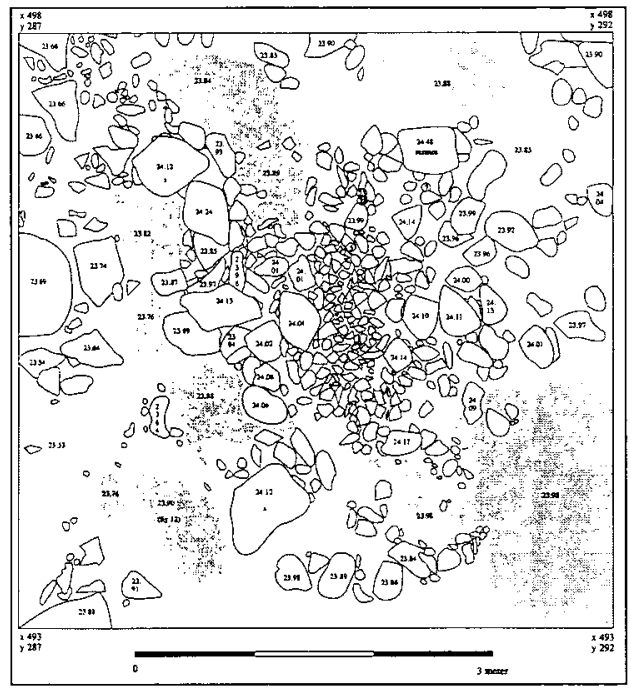

Fig. 4. Stone-setting from Yttertavle, Umeå parish, in Västerbotten. The stone-setting was classified as rectangular in shape before excavation. As can be seen, this shape is not discernible and can therefore be questioned. After Goldhahn 1996:15.

subsequently lost their former shape and finally became incomparable to each other. These phases of constant rebuilding, illustrated above, and the frequency of the "disturbed" exterior, support the suggestion that many cairns were used repeatedly not only during the Bronze Age but also during the Iron Age (according to dating from shore-level displacement). It is hard to determine exactly to

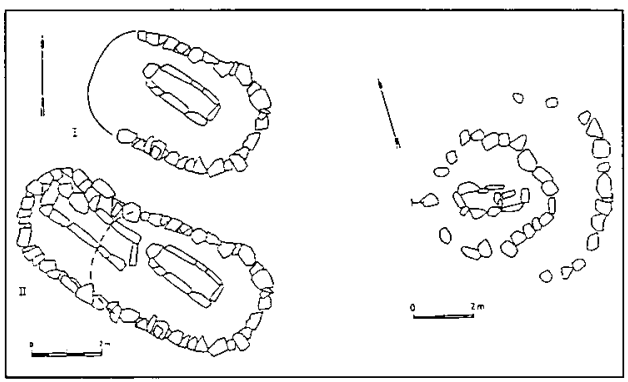

Fig. 5. Different phases of rebuilding. To the left, rebuilding of cairn 29:2, Vibyggera parish. The cairn was rebuilt from phase I to ll and was extended in the western part. To the right, rebuilding of cairn 10:2, Själevad parish. Originally the cairn 10:2 contained a cist of a man's length, which in a later stage was divided. Rearranged after Baudou 1968:33, 40 . 
what extent the cairns and cairn-like stonesettings were reused and reconstructed. According to Baudous' survey, the main part of the excavated cairns showed traces of later external influences. I will suggest that most of the cairns were involved in the same rebuilding practice. This brings us back to the questions posed in the beginning of the article: What was the meaning of the cairns? Who built them, and what where the intentions of the people in doing so?

\section{THE RITUAL USE OF CAIRNS}

I will here present an interpretation of the cairns as a kind of long-term monument, frequently used by local kinship-groups for ritual purposes. This interpretation is quite different from the one that associates the cairns with permanent and completed individual burials.
According to the idea of repeated rebuilding that was suggested above, the bonedepositions were just one part of something else. In my opinion, they were one part of a ritual process in which the cairns were repeatedly rebuilt and activated. In such a ritual the cairnmonument was a medium, not an end in the sense of a permanent and completed manifestation of an individual burial. Ethnography demonstrates that the bones of ancestral persons can frequently take on the character of artefacts, circulated among kin or kept in significant locations (Thomas 1996:173). In this study there is evidence for only small amounts of bones being ritually deposited in the cairns. Still, very little is known about the mortuary practices in Norrland during the Bronze Age. The cairns have already been mentioned, but as noted earlier, we cannot interpret them as representing individual burials in

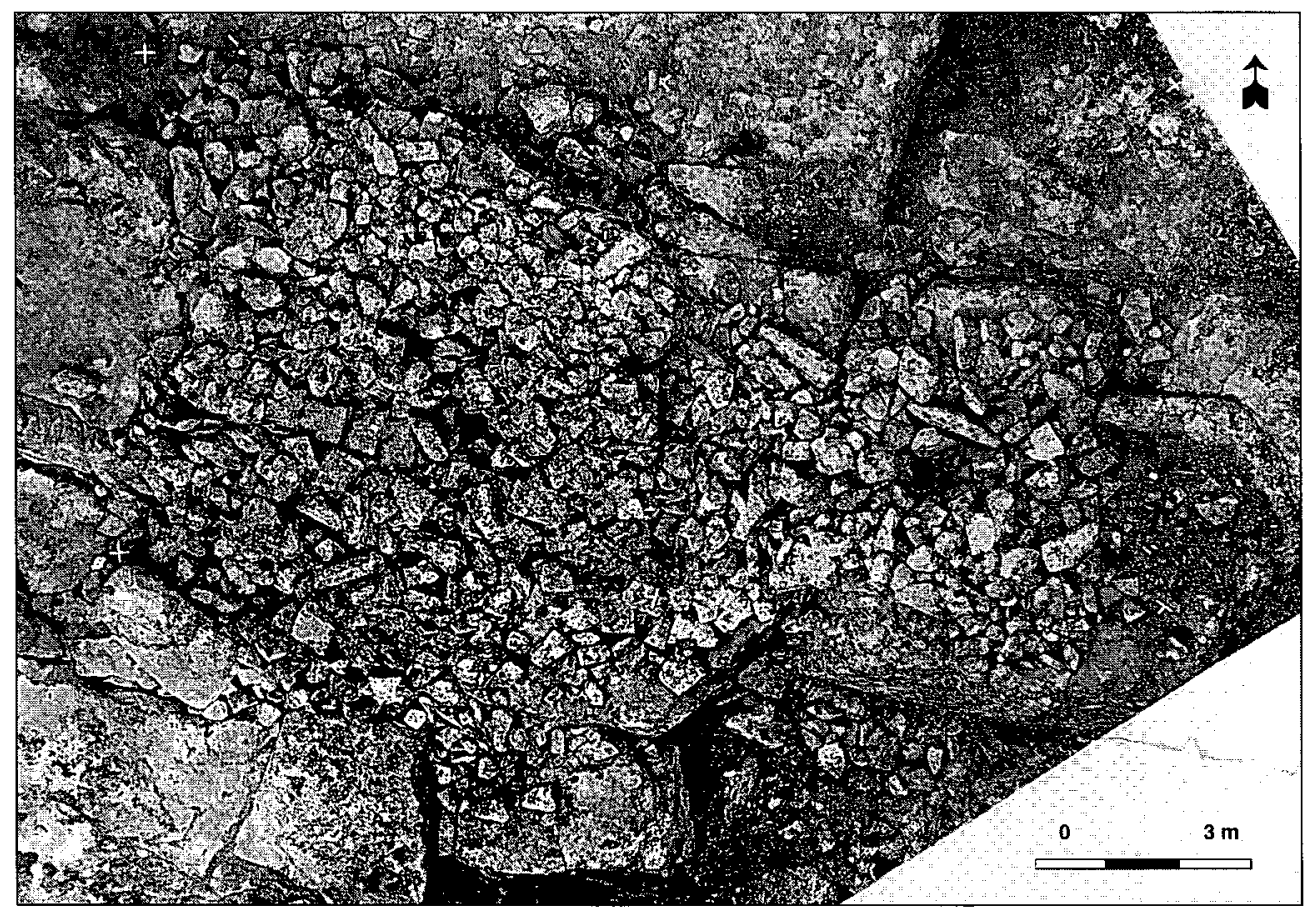

Fig. 6. The caim-structure Sund 27:7-9, in Vibyggerå parish, is an illuminating example of rebuilding phases, re-constructions and indeterminable shape. This cairn-monument is about $12 \mathrm{~m}$ long, $6 \mathrm{~m}$ wide, and $0.7 \mathrm{~m}$ high. It is hardly possible to distinguish any determinable morphology in this cairn-building, although some remains of the external architecture can be seen in the middle of the picture. Photo: The Antiquarian-Topographical Archive, Stockholm. 
the same way as we know them during the Iron Age and later (e.g. Selinge 1979:194). Every society has its own "burial" custom, and it is not reasonable to expect that all such customs would be materially manifest and lasting. Several attempts have been made to explain the limited number of cairns from different functionalist points of departure. The number of cairns is usually related to the number of people buried. Baudou, for example, has suggested that the cairns represent the burial custom of an ordinary coastal settlement-unit (Baudou 1968:132). However, according to Kristiansen, the limited number of cairns should instead be considered as the burial practice of the social elite (Kristiansen 1987:74-85). The theoretical approaches to the cairn-issue have, in my opinion, proceeded to great extent from the physical remains to define social rank, chiefs, settlement patterns and economic subsistence, but almost no attempts have been made to define the implications of the building and rebuilding of cairns.

What kinds of monuments did the cairns represent and what motives and intentions lay behind the repeated deposition of bones and the rebuilding of the cairns? A widely held suggestion concerning the underlying motives behind religious sacrifices, ritual ceremonies and festivals, is the attempt to maintain and support the existing "world-view" or "cosmological" order within a society or group over time (e.g. Eliade 1987; Leach 1982; Lundmark 1984). The sacrificial rituals may vary from one society to another, but the motives are generally to receive luck, prosperity, forgiveness, stability, safety, fertility, etc., from the higher powers of both ancestors and gods. It is reasonable to suggest that the ritual use of the cairn-monuments also aimed at creating contact between the living society and the spirits of the ancestors. In this practice the cairns and stone-settings became a medium through which the contact with the ancestral spirits could be channelled. The re-use of cairns seems to have been of very great importance as a ritual institution aimed at maintaining social stability. According to Eliade, archaic and traditional societies strive to enter the "mythical" and "sacred" time through the rites. Every religious festival or ceremony represents the re-actualization of a sacred event that took place in a mythical past (Eliade 1987:68-69). Sacred time is indefinitely recoverable and indefinitely repeatable, according to Eliade, and it is possible that the rebuilding of cairns and cairn-like stone-settings was also done in an attempt to re-actualize the sacred and mythical past.

Most part of the cairns and cairn-like stonesettings in Norrland are located close to the ancient shore. Ritual phenomena in close connection to water-contexts are, according to Eliade, usually associated with a religious symbolism, such as purification and communication with ancestral spirits (ibid 1987:139). The "religious man", to use Eliade's terminology, creates his myths and his rituals in an attempt to come to terms with the physical decomposition of the dead body and the phases of initiation and change in life. Repeated rituals and religious practices can be described as an ideological "vehicle" which serves to support, but also to maintain, the "cosmological" order.

The cairns along the coast are situated either isolated or sometimes agglomerated in groups with up to ten structures. Figure 7 shows the distribution of cairns and cairn-like stone-settings in the river-mouth area of the Angerman River. Each structure is here suggested to be associated with a specific kinship-group among the coastal dwellers. The occurrence of several cairns within one area signifies new establishments and perhaps a break within the constitution of the local kinship-structure. The establishment of new structures within an area can perhaps be seen as an expression of competition between kinship groups within the coastal community.

Bones from humans and animals were used in different ritual activities within the kinship group. Animals were perhaps sacrificed for different purposes, while the remains from humans had another ritual significance. Former deposits were frequently collected 
and replaced with new deposits. Small amounts of bones were used to activate the cairns and make possible the ritual communication with the ancestral spirits. An illuminating metaphor of the cairn-ritual is given by the early Catholic churches in medieval Europe and the worship of relics. In a similar way as the early churches, the cairns could have expressed an ordered religious universe. It is important to make clear that this analogy should not be taken in a literal sense. The cairns as well as the early churches were originally built on sites of great ritual impor-

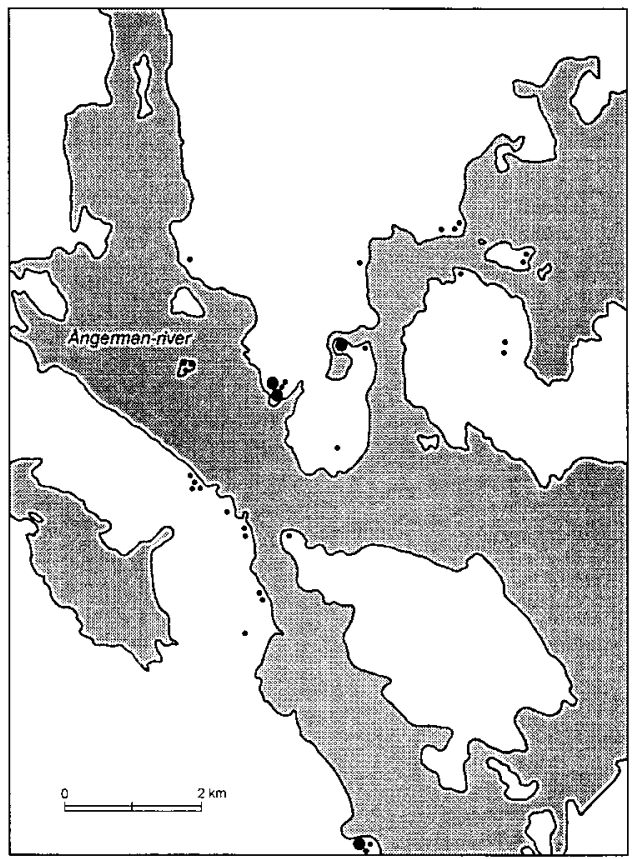

Fig. 7. The distribution of cairns and caim-like monuments in the river-mouth area of the Angerman River in Angermanland. Most of the cains were located close to the ancient shore. The bigger dots represent several monuments agglomerated.

tance, such as the burial-ground of an (mythical) ancestor. The remains of larger cists in some of the cairns are perhaps a reminiscence of such an early establishment. In a similar way as the Christian churches, the cairns on several occasions were deliberately rebuilt and reconstructed. Every new establishment and every new rebuilding can be considered to represent the re-actualization of the sacred time and the mythical past. The cairns (as well as the churches) came to have several meanings on different levels. One was to legitimate the local kinship-structure and the different types of social relations. This means that each cairn was related to a particular kinship-group. Another meaning was to serve as a religious monument and a ritual medium that was frequently activated and re-constructed. This means that cairns, in general, were instruments for establishing contact with the higher powers. The cairns should simultaneously be considered as both a ritual medium and as a "social institution" for the inhabitants of the coastal region. In this respect they were both guiding and ordering the social and cosmological world.

According to the ritual practice that is here suggested to be associated with the cairns and stone-settings, the motives behind the depositions in the cairns were to maintain, or perhaps also to obtain, safety and benevolent power from the higher gods and spirits. They were built as ritual monuments and they were used in different ceremonies and festivals, and as such (an institution) they also served to reproduce the ancestral myths and the local narrative.

\section{CONCLUDING REMARKS}

It is necessary to scrutinize the relevance in using the terms "grave" and "burial" in prehistoric contexts. Ethnography shows a wide range of mortuary practices without any manifest or long-lasting constructions. Actually, we don't know what the people in Norrland actually did with their dead family members, whether they buried them or deposited them on the ground, in the water or somewhere else. The deposition of cremated and uncremated bones in the cairns was, in my opinion, not necessarily always intended as permanent individual burials, as has sometimes been proposed.

In this article I have tried to illuminate the ritual significance and the ritual use of cairns in Bronze Age Norrland. The cairns along the 
Norrlandic coast were continuously in use. They were frequently rebuilt for ritual purposes and consequently the external structures were altered in a number of ways. It is therefore not an easy task to classify the cairnstructures in a unified and coherent way. The scanty find-material that has been recovered from the cairns and from the cairn-like stonesettings primarily consists of small amounts of burnt and unburnt bones. The interpretation made here suggests that the depositions of bones were intended to activate the cairns in an attempt to communicate with the ancestral spirits during the whole Bronze Age and onwards.

This discussion has so far mainly centred upon the conditions in the coastal areas. I have deliberately avoided touching upon the "significant" division between the coastal "cairn-area" and the "cairn-less" interior of Norrland. A few words concerning the relations between the coast and the interior can perhaps serve as a concluding remark in this article. The social and economic structure in Bronze Age Norrland has by several archaeologists been viewed as a dualism between the coast and the inland area. This is usually described as a dualism between two different cultural and economical systems (e.g. Bakka 1976; Baudou 1977; Forsberg 1992; Kristiansen 1987). According to Kristiansen, for example, there was an egalitarian structure with hunter-gatherers in the interior of Norrland, and a more complex and socially stratified order with "ranked" farmers buried in cairns along the coast. The cairn-building tradition is, undoubtedly, one of the more evident material differences between interior and coast in Bronze Age Norrland. The crux of the matter is, in my opinion, how to interpret the cultural significance of the archaeological material within these areas in a less schematic way. The correlation between subsistence economy and social complexity on the one hand, and the presence or absence of cairns on the other, is a much too simplified argument. I am not so sure whether the presence and absence of cairns can actually be described as a dualism of "cultures", or any other kind of reified social entities, polarized between the two areas. Besides, there are other materialpatterns that can be said to cast doubt on this kind of dualist approach. In any case, that is an issue to be disentangled elsewhere.

English revised by Laura Wrang. 


\section{REFERENCES}

Bakka, E. 1976. Arktisk og nordisk i bronsealderen $i$ Nordskandinavien. Trondheim.

Baudou, E. 1968. Forntida bebyggelse i Angermanlands kustland. Arkiv för norrländsk hembygdsforskning. Härnösand.

- 1977. Den förhistoriska fångstkulturen i Västernorrland. Västernorlands forhistoria. Västernorrlands läns landsting. Härnösand.

- 1992. Norrlands forntid - ett historiskt perspektiv. Wiken.

Barrett, J. 1994. Fragments from Antiquity. An Archaeology of Social Life in Britain, 2900 $1200 \mathrm{BC}$. Oxford.

Bradley, R. 1993. Altering the Earth. The Origins of Monuments in Britain and Continental Europe. Edinburgh.

Carr, C. \& Neitzel, J. 1995. Integrating approaches to material style. Style, Society and Person. Archaeologicaland Ethnological Perspectives. Pp. 3-30. New York.

Forsberg, L. 1992. De norrländska hällbildernas sociala kontext - alternativa tolkningar. Arkeologi i Norr Nr 3 1990. Pp. 55-69. Umeà.

Goldhahn, J. 1997. Röse och stensättning vid Yttertavle 1:14, Umeà sn. Västerbotten. Preliminär rapport från en seminarieutgrävning vt 1996. Umark 5. Umeå.

Eliade, M. 1987. The Sacred and the Profane. New York.

Hyenstrand, А. 1966. Igelstakomplexet. Kring yngre bronsålder i Mälarområdet. Stockholm.

- 1979. Ancient Monuments and Prehistoric Society. Riksantikvarieämbetet. Stockholm.

Jennbert, K. 1993. Släkters hågkomst. Om bruket av bronsåldershögar. In: Larsson, L. (Ed.) Bronsålderns gravhögar: University of Lund, Institute of Archaeology, Report Series No. 48. Pp 69-78. Lund.

Kaliff, A. 1997. Grav och kultplats. Eskatologiska föreställningar under yngre bronsailder och äldre järnålder $i$ Östergötland. Uppsala.

Kristiansen, K. 1987. Centre and periphery in
Bronze Age Scandinavia. Centre and Periphery in the Ancient World. Pp. 74-85. Cambridge.

Larsson, T. B. 1994. Bronsålder. Stenålder, Bronsålder, Jämålder. Signums svenska konsthistoria. Pp. 69-161. Lund.

Leach, E. 1982. Social Anthropology: Cambridge.

Loeffler, D. 1991. Fornlämningsbeståndet i Nora socken, Ångermanland. Angermanland Medelpad 1990-91. Pp. 53-76.

Lundmark, L. 1984. Det förflutnas makt. Stockholm.

Olausson, D. 1993. The Bronze Age Barrow as a Symbol. In: Larsson, L. (Ed). Bronsålderns gravhögar. University of Lund, Institute of Archaeology, Report Series No. 48. Pp 91-113. Lund.

Salo, U. 1983. Bronsåldersamhället vid Satakuntakusten: källor och tolkningsförsök. Foredrag ved det I. Nordiske bronsealdersymposium pa Isegran 3-6 oktober 1977. Pp. 1-14. Oslo.

Selinge, K-G. 1974. Kulturlandskapet-översiktlig dokumentationoch planering. Riksantikvarieämbetet Rapport D4. Stockholm.

- 1979. Agrarian Settlements and Hunting Grounds. A Study of the Prehistoric Culture Systems in a North Swedish River Valley. Stockholm.

- 1986. Stensättningar med variation. Om en fornlämningsterm - med västgötska exempel.Arkeologi i Sverige 1984. Pp. 7-50. Stockholm.

Stjernquist, B. 1993. Perspectives on Monumental Bronze Age Graves along the Southern Edge of Fenno-Scandia. In: Larsson, L. (Ed). Bronsålderns gravhögar. University of Lund, Institute of Archaeology, Report Series No. 48. Pp 115 131. Lund.

Thomas, J. 1996. Time, Culture and Identity. London.

Thålin, H. 1966. Fornlämningstyper och nivåförhållanden iövre Norrlands kustland. Västerbotten. Pp. 108-114.

Wallman, J. H. 1838. Öfversikt af svenska fornlemningar med anvisning till deras kännedom och beskrifning. Kungliga Vitterhets Historie och Antikvitets Akademien. Stockholm. 